\title{
Articulação federativa na prestação de serviços sociais no Brasil
}

Aldino Graef

\section{Introdução}

O novo pacto federativo, estabelecido no país após os 20 anos de regime militar, constitui um dos pilares do processo de redemocratização nacional. A excessiva centralização administrativa e política no Poder Executivo Federal, ocorrida no período da ditadura militar, havia ocasionado a perda de espaço político e de autonomia dos estados e municípios brasileiros a tal ponto que os estados passaram a ter governadores designados diretamente pelo governo federal. O enfraquecimento da capacidade executiva dos governos subnacionais e a centralização federal, aliados ao modelo desenvolvimentista adotado pelos governos militares, produziram a expansão da estrutura administrativa do Executivo Federal, especialmente da administração indireta, com a proliferação de autarquias, fundações públicas de direito privado e empresas estatais.

Segundo levantamento efetuado pela extinta Secretaria de Administração Pública da Presidência da República (Sedap), no ano de 1987, a administração 
federal direta contava com 570.991 servidores públicos civis que, somados aos 1.006.490 empregados das entidades da administração indireta, perfazia um total de 1.577.481 servidores públicos civis na União. Esse quantitativo representava, na época, $25 \%$ do total nacional de servidores públicos. Os estados federados eram responsáveis por $50 \%$ do total de servidores enquanto que nos municípios - onde efetivamente as pessoas moram e demandam diretamente a atuação do Estado havia apenas $25 \%$ do total de servidores públicos civis.

O novo pacto federativo envolveu ampla descentralização de serviços públicos para estados e municípios, especialmente nas áreas sociais, e uma nova estrutura de repartição dos recursos tributários. Os governos estaduais e municipais recuperaram a autonomia político-administrativa. A partir de 1982, antes mesmo da instalação do novo governo civil (em 1985) e da Assembleia Nacional Constituinte aprovar a nova Constituição, os governadores estaduais voltaram a ser eleitos, pelo voto universal, direto e secreto da população.

$\mathrm{Na}$ verdade, a descentralização administrativa conformou-se como uma das diretrizes fundamentais da Constituição democrática de 1988. O texto magno contemplou a garantia dos direitos fundamentais, a ampliação dos direitos sociais universais e a responsabilização compartilhada das três esferas executivas do Estado, por meio da ação intrafederativa articulada e integrada na oferta de bens e serviços à população.

A seguridade social, composta pelas políticas de saúde, previdência e assistência social, foi introduzida pela Constituição como um direito social universal, o que constituiu importante conquista dos trabalhadores e de toda a sociedade brasileira, duramente reprimida durante o período $\mathrm{da}$ ditadura. Interessante notar que o mesmo capítulo do texto constitucional que institui novos direitos - como o segurodesemprego; a previdência social, sem distinção entre trabalhadores rurais e urbanos; o acesso universal e gratuito à assistência à saúde e, também, à assistência social aos necessitados - prevê que esses serão assegurados pela ação organizada e integrada das três esferas de governo e da sociedade civil; determina ainda a constituição de um sistema único de saúde e ações de assistência social da União para os estados, o Distrito Federal e os municípios.

A Constituição Cidadã combinou a redemocratização do país com a ampliação dos direitos sociais; a universalização do acesso aos serviços públicos e a descentralização de sua prestação direta para os entes subnacionais de governo, ainda que a combinação perfeita desses elementos tenha-se dado mais no plano ideológico. No entanto, a implantação de fato dos novos direitos sociais e da descentralização no contexto do novo pacto federativo revelou-se um processo complexo e conflitivo, por essência, agravado pela crise financeira enfrentada pelo Estado Brasileiro nos anos que se seguiram à promulgação da Carta Magna.

Importante ressaltar que, especialmente após os anos 1980, o fenômeno da descentralização e da federalização dos estados constituiu uma das macrotendências observadas na organização das estruturas estatais em todo o mundo, reforçada, em grande parte, pela queda do socialismo; pela ruptura da concepção desenvolvimentista do Terceiro Mundo e pela falência do Estado social hegemônico, contraparte do fenômeno da globalização. Embora sintonizado com o quadro geral, o processo de descentralização brasileiro 
deu-se mais pelos fatores internos, de superação do regime autoritário e do movimento de democratização colocado em curso, que culmina com a reconfiguração institucional do federalismo na Constituição de 1988 e com a explícita valorização do poder local (PIREs e Nogueira, 2009).

O princípio federativo constante do caput do art. 1ํㅡㄹ da Constituição desdobrase ao longo de todo o texto, seja nos dispositivos que tratam da organização do Estado (Título III), seja como estratégia à implantação das políticas setoriais, e demonstra uma opção inequívoca em favor do fortalecimento do ente municipal. A previsão constitucional é emblemática, sinaliza a inversão do movimento expansionista do poder central, ocorrida durante a ditadura, e anuncia a ampliação do papel do município, contemplado com competências oriundas diretamente da matriz constitucional (Pires e Nogueira, 2009).

Feito o balanço dos avanços e retrocessos da administração pública brasileira pós-Constituição de 1988, em meio às sucessivas tentativas de superação da crise fiscal originada na crescente dívida pública, vê-se que houve avanços significativos, ainda que não sistematizados, impulsionados pela absorção de novas tecnologias de informação e comunicação institucionais - que impactaram positivamente os métodos de gestão do setor público, notadamente na área de prestação de serviços voltados para o mercado - e também pela vivência ininterrupta dos 20 anos de normalidade democrática, durante os quais registraramse lutas políticas internas, próprias de uma sociedade que tenta construir as bases para a democracia plena.

Embora de forma mitigada, em processo tumultuado e, muitas vezes, ameaçado, implantou-se um novo modelo de seguridade social assim como se efetivou a descentralização de serviços sociais para estados e municípios, sendo geradas novas formas de articulação federativa e novos instrumentos de gestão da prestação de serviços públicos.

Em um quarto de século, operaramse profundas mudanças no país e, consequentemente, na administração pública brasileira, em reflexo às mudanças políticas, econômicas, sociais e culturais internas e

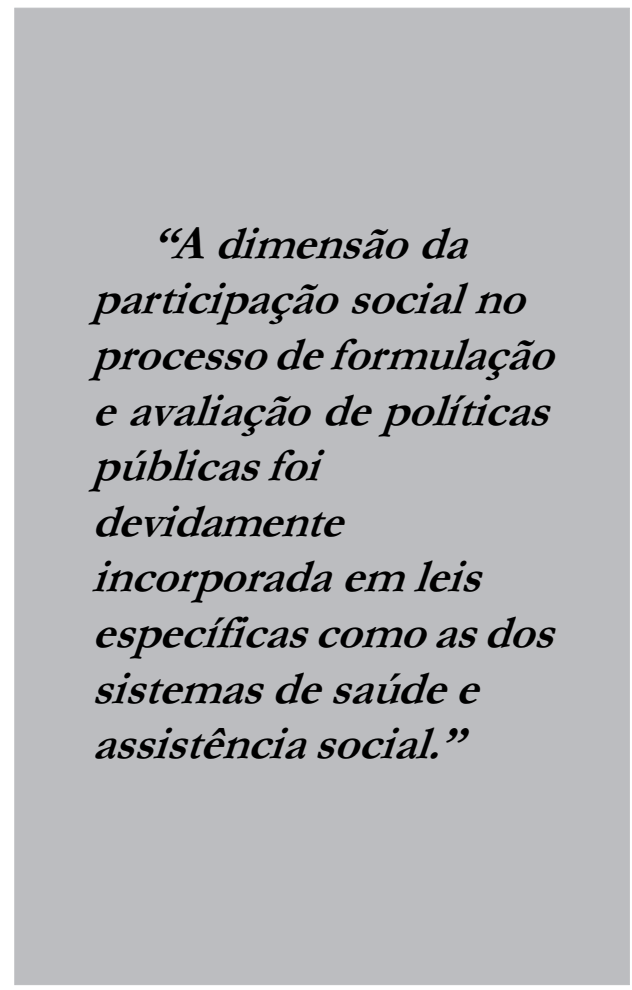

internacionais, que impulsionaram para o redesenho das relações federativas.

\section{A reorganização no âmbito federal e o início da descentralização}

O período imediatamente posterior à promulgação da Constituição Federal de 1988 é conhecido como a "era do 
desmonte", em função do conjunto de políticas liberais adotadas para privilegiar o ajuste econômico, a desregulamentação, a desestatização e a abertura da economia ao capital externo. Presidente eleito nas primeiras eleições diretas, pós-ditadura, Fernando Collor de Melo adotou medidas de abertura do mercado nacional, incluindo o fim da reserva de mercado na área de informática; uma política de redução de gastos públicos na perspectiva do controle do processo inflacionário; e a redução do tamanho do Estado, como parte da concepção liberal-democrática, também presente no processo de redemocratização.

Embora o tema da descentralização administrativa estivesse presente no discurso do projeto Collor de Melo, desde a campanha eleitoral, era perceptível a concepção ultraliberal de Estado mínimo que embasava o discurso do então candidato, centrado no ataque a supostos privilégios de servidores públicos e na defesa da redução do tamanho do Estado.

O Governo Collor iniciou-se com um choque de gestão, centrado na extinção de dezenas de empresas e órgãos públicos e na disponibilidade de aproximadamente 112 mil servidores públicos federais e aposentadoria de 45 mil, em um processo tumultuado no qual predominou a falta de critérios e uma postura autoritária. Das medidas de enxugamento da máquina adotadas à época, nenhuma deixou resultados perenes, seja pelo impacto na cultura, seja pelos métodos, técnicos ou processos utilizados. De fato, vários dos órgãos e entidades extintos foram, posteriormente, reconstituídos e a quase totalidade dos servidores demitidos ou colocados em disponibilidade conseguiram voltar à ativa. O desmonte gerou prejuízos significativos para a administração pública federal, especial- mente em função da perda de memória, conhecimento e competência das instituições, seja pela desestruturação dos arranjos institucionais burocráticos constituídos até então.

No entanto, como grande parte das leis regulamentadoras do texto constitucional recém-aprovado ainda estava em elaboração ou tramitação e os estados e municípios ainda não haviam concluído o processo de adaptação de suas constituições estaduais e leis orgânicas municipais à Carta Federal, o processo de descentralização não foi igualmente afetado, vindo a ocorrer mais tarde. Datam desse período a reorganização do sistema previdenciário, com a unificação dos antigos institutos no Instituto Nacional do Seguro Social (INSS); a regulamentação do seguro-desemprego e a organização da sua estrutura de suporte técnico-administrativa. Ressalte-se, contudo, que a previdência social e a concessão do seguro-desemprego permaneceram como competências da União.

A implantação do Sistema Único de Saúde (SUS), com base na Lei no ${ }^{\circ}$ 8.080/90, a partir da extinção do Instituto Nacional de Assistência Médica da Previdência Social (Inamps), passou por diversas fases e dificuldades de absorção pelos municípios dos grandes hospitais, especialmente no Rio de Janeiro. O que orientou a organização do SUS foi mais o financiamento, de cunho federal, do que os ditames das leis que o regulamentaram, os resultados pretendidos ou as necessidades do sistema (SAntos e ANdrade, 2007).

À medida que a legislação regulamentadora dos dispositivos constitucionais começou a ser aprovada, foram moldados os sistemas descentralizados de prestação de serviços, com especificidades nas formas de articulação federativas, 
relacionadas às respectivas áreas de atuação, como se verá a seguir.

\section{O modelo de articulação da educação}

A obrigatoriedade, a gratuidade e a universalidade do acesso à educação básica no Brasil estão asseguradas pela Constituição desde a Carta de 1934. Já na Constituição Federal de 1967, havia a previsão de que os serviços públicos de ensino deveriam se organizar de forma sistêmica, cabendo à esfera federal, o caráter supletivo.

Vê-se, portanto, que desde sua origem a educação básica desenvolveu-se no país de forma descentralizada. Durante as décadas de 1960 e 70, a política de massificação do ensino, resultou na expansão das redes dos estados e dos municípios, havendo o governo federal concentrado esforços na expansão do ensino universitário e técnico-profissional, tida como essencial pela ditadura militar para o êxito do projeto nacional-desenvolvimentista.

Desde aquela época, a União reservara para si o papel de formuladora da política nacional de educação básica e uma atuação suplementar, com a implementação de programas de apoio pedagógico, na formação e aperfeiçoamento de professores e no suprimento de materiais didáticos, a exemplo do Programa Nacional do Livro Didático; do Programa Nacional de Alimentação Escolar e do programa de manutenção e construção de escolas.

Para custeio dessa atividade suplementar da União e, ainda, para conceder aporte adicional de recursos para as redes estaduais e municipais de ensino, na década de 1970, foi criada uma contribuição, incidente na folha salarial das empresas, denominada "salário-educação", assim como o Fundo
Nacional de Desenvolvimento da Educação (FNDE), específico para gerir esses recursos. Dois terços do total arrecadado eram distribuídos aos estados e municípios, enquanto que um terço era destinado às atividades suplementares da União.

Essa divisão de competências entre União, estados e municípios foi consagrada no texto constitucional de 1988 que, em seu art. 211, estabeleceu que "a União, os estados o Distrito Federal e os municípios organizarão em regime de colaboração seus sistemas de ensino". O dispositivo atribuiu à União a responsabilidade de organizar e financiar o sistema federal de ensino, além de exercer a "função redistributiva e supletiva", no que se refere aos sistemas educacionais dos estados e municípios, "de forma a garantir a equalização de oportunidades educacionais e um padrão mínimo de qualidade do ensino mediante assistência técnica e financeira aos estados, ao Distrito Federal e aos municípios". ${ }^{1}$

A Constituição previu, ainda, que aos municípios caberia atuar, prioritariamente, no ensino fundamental e na educação infantil enquanto que os estados deveriam se ocupar do ensino fundamental e médio, mediante atuação em regime de colaboração, para assegurar a universalização do ensino obrigatório ${ }^{2}$.

Das inovações introduzidas pela Constituição de 1988 na área da educação, destaca-se o fato de haver vinculado parcelas das receitas fiscais auferidas pelas três esferas de governo para a manutenção e desenvolvimento do ensino ${ }^{3}$. A esse respeito, cumpre destacar que logo que implantada, essa vinculação evidenciou a existência de graves distorções no esquema de distribuição linear de responsabilidades entre estados e municípios, além de desníveis no desenvolvimento econômico existente entre as regiões. 
Em situações como a de São Paulo, constatou-se a existência de uma rede de ensino quase que exclusivamente estadual, financiada com recursos majoritariamente do estado, superiores ao percentual constitucional de investimento. No entanto, existia em São Paulo uma série de municípios, com alto nível de desenvolvimento, praticamente sem possuir rede própria de ensino e, consequentemente, sem ter como aplicar os recursos vinculados.

Em outras situações, notadamente em regiões com níveis mais baixos de desenvolvimento, como o Nordeste, verificou-se que as redes eram basicamente municipais e os estados não tinham redes significativas.

Para superar esses problemas, criouse o Fundo de Desenvolvimento da Educação Fundamental (Fundef) ${ }^{4}$, que aglutinou $60 \%$ dos recursos vinculados dos estados e respectivos municípios em fundos estaduais para a manutenção e desenvolvimento do ensino fundamental, com redistribuição para as respectivas redes de ensino. O critério de redistribuição utilizado foi o do número de alunos de cada rede, de forma que quanto mais alunos houvesse na rede, mais recursos ela receberia. Estabeleceu-se, ainda, um valor mínimo de financiamento por aluno/ano para que os fundos estaduais com menor volume de arrecadação de impostos, cuja média por aluno fosse inferior ao valor mínimo nacional de financiamento, passassem a receber uma complementação de recursos da União. Desde então, o governo federal tem suplementado, com recursos adicionais do orçamento da União, os fundos dos estados menos desenvolvidos.

Em 2006, essa sistemática foi estendida à educação infantil e ao ensino médio, por meio da criação do Fundo de Manutenção e Desenvolvimento da Educação Básica (Fundeb) ${ }^{5}$, que substituiu o Fundef. Uma vez que o novo sistema de financiamento fundamentava a distribuição de recursos no número de alunos matriculados por escola e por rede de ensino, o censo educacional, realizado a cada cinco anos, tornou-se anual, para gerar a informação necessária à operacionalização do Fundef.

A medida disponibilizou ainda, às três esferas de governo, um importante conjunto de indicadores educacionais, obtidos junto aos alunos, professores e escolas, que permitiu ao poder público identificar problemas relativos à matrícula e à evasão escolar em cada localidade, aos processos de passagem entre as séries e ciclos, bem como sua relação com a formação dos professores e a infraestrutura escolar. Esse rol de indicadores tem sido utilizado como valioso subsídio pelo Ministério da Educação (MEC), assim como pelas secretarias estaduais e municipais de educação, na definição de políticas de melhoria do desempenho institucional e da qualidade do ensino.

A preocupação com a avaliação do desempenho da rede nacional de educação não se esgotou nesse sistema de indicadores, sendo instituídos e reformulados diversos outros mecanismos de avaliação da qualidade do ensino para subsídios ao processo de formulação da política educacional, tais como o Sistema Nacional de Avaliação da Educação Básica (Saeb) desenvolvido pelo MEC -, que avalia o aprendizado dos alunos em intervalos de tempo de poucos anos, por meio de provas específicas, e o Exame Nacional do Ensino Médio (Enem), que avalia os egressos desse nível de ensino. O cruzamento dos dados relativos ao censo educacional com os do Saeb permite a produção de indicadores qualitativos sobre 
o desempenho da educação no país, nos estados, nos municípios e em cada escola especificamente.

Recentemente, o Ministério da Educação criou o Índice de Desempenho da Educação Básica (Ideb), que constitui um indicador síntese de desenvolvimento educacional para cada rede de ensino e escola. A partir do Ideb, tornou-se possível estabelecer critérios para os repasses de recursos do Fundeb, assim como dos recursos complementares do FNDE vinculados a este indicador.

Atualmente, o MEC tem condições de identificar o nível de desempenho na execução das políticas educacionais pelos entes da federação e pelas instituições públicas federais, de forma a premiar o bom desempenho educacional ou adotar medidas corretivas, que visem à superação de deficiências ou à melhoria na performance do ensino público brasileiro.

Importante destacar que a participação complementar da União no financiamento da educação básica nos estados menos desenvolvidos permite a indução das redes de ensino estaduais e municipais, a partir da política alocativa, como reforço em relação aos resultados observados no censo educacional e no sistema de avaliação, expressados nos indicadores educacionais.

Tem-se, portanto, no sistema de financiamento concebido para o setor, por meio do Fundef/Fundeb, um dos principais responsáveis pelo entrelaçamento dos entes federativos na manutenção e desenvolvimento da rede nacional de educação básica e pela relativa superação da estrita divisão de competências entre os estados e os municípios.

A divisão geral de responsabilidades definida na Constituição permanece intacta, assim como permanece intocado o princípio da autonomia dos entes da federação. Porém, na perspectiva de maior equalização das responsabilidades financeiras no financiamento da educação básica, o Estado Brasileiro evoluiu para uma forma de articulação federativa peculiar, com arranjo específico para o campo da educação, distinto dos demais arranjos setoriais, que tem produzido resultados positivos e benefícios para o país.

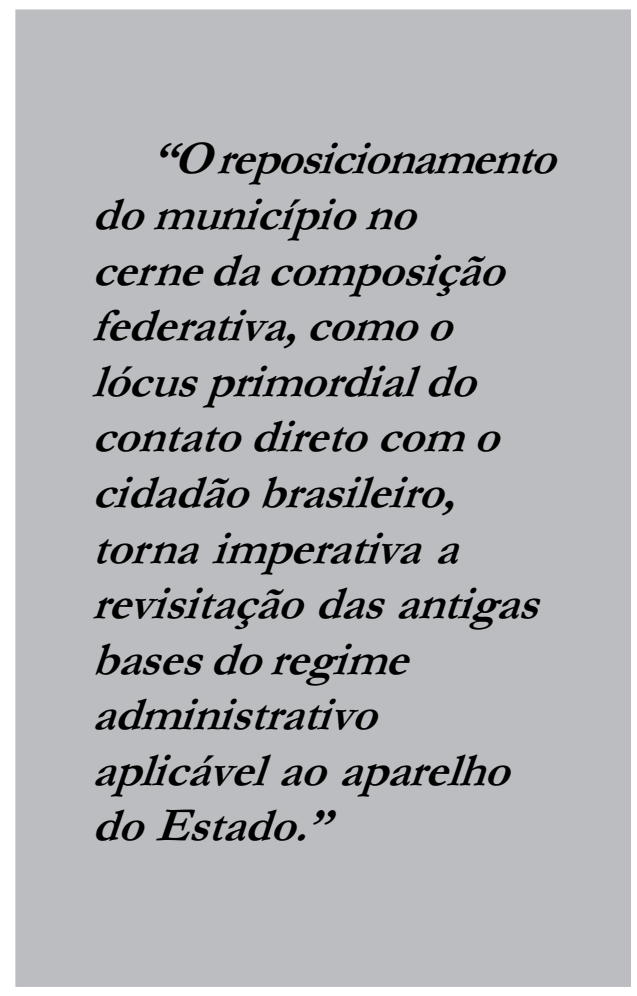

\section{O modelo de articulação do Sistema Único de Saúde (SUS)}

A saúde pública gratuita e universal é uma conquista da sociedade brasileira alcançada no processo constituinte que resultou na Carta Magna de 1988. Anteriormente, a maioria da população do país não tinha acesso aos serviços de saúde gratuitos, restritos tão 
somente aos filiados à previdência social. Grande parte dos hospitais e centros de atendimento era privada ou pertencente a entidades beneficentes e filantrópicas. Quem podia pagar recorria a hospitais privados. A população pobre, excluída do mercado formal de trabalho, não tinha acesso à assistência da saúde pública, tendo como alternativa, recorrer à beneficência e às ações de caridade ligadas à Igreja.

A Nova Constituição reconheceu a saúde pública como direito do cidadão e dever do Estado, a ser garantido por meio de políticas que assegurassem o acesso universal e igualitário. $\mathrm{O}$ texto constitucional inovou ao estabelecer, nos seus arts. $197 \mathrm{e}$ 198, que os serviços de saúde, executados diretamente ou por terceiros, são de relevância pública e que as ações e serviços de saúde nacionais devem ser organizados em rede regionalizada e hierarquizada, em sistema único, cujas diretrizes fundamentais são a descentralização; o atendimento integral e a participação da comunidade. Determinou, portanto, a substituição do modelo centralizado de prestação de serviços de saúde por um fundamentado na corresponsabilidade entre os entes federativos, inclusive no que se refere ao seu financiamento que, na forma do disposto no $\int 1^{\circ}$ do art. 198, foi fixado como um dever da União, dos estados, do Distrito Federal e dos municípios (SANTOS \& ANDRAdE, 2007).

Desde então, materializar os arrojos constitucionais e promover a reforma do Estado no setor da saúde pública tem sido um desafio, superado gradativamente, em um processo longo e complexo. Em 1990, a Lei $\mathrm{n}^{-} 8.080 / 90$, complementada pela Lei $\mathrm{n}^{-}$8.142/90, disciplinou o Sistema Único de Saúde (SUS) e estabeleceu a divisão de competências entre as três esferas de governo, atribuindo à União o exercício das funções de direção nacional, por intermédio do Ministério da Saúde 6 . Às esferas estaduais do SUS, coube acompanhar, avaliar e controlar as redes hierarquizadas do Sistema na sua região e exercer, em caráter suplementar, ações e serviços em áreas específicas. As direções municipais ficaram encarregadas do planejamento, da organização e da execução das ações e serviços de saúde no âmbito local.

Ao setor privado, a lei reservou a participação no SUS mediante contratos ou convênios com o poder público, priorizando as entidades privadas sem fins lucrativos. A legislação disciplinou, também, a participação da comunidade na gestão do SUS; as transferências intergovernamentais de recursos financeiros na área da saúde e instituiu os Conselhos de Saúde e as Conferências de Saúde em todos os níveis de governo.

Interessante notar que, a despeito da complexidade inerente à implantação de um sistema intrafederativo de prestação de serviços, a legislação básica original do SUS permaneceu intacta e vigente até a atualidade, à exceção de poucas alterações legais?

A organização do Sistema realizou-se com base em Normas Operacionais Básicas (NOBs) do Ministério da Saúde, que ditavam procedimentos para os estados e municípios interessados nas transferências financeiras federais.

A edição das NOBs marcou as diversas fases de implantação e organização do SUS, sendo importante destacar o papel da NOB-SUS 01/93, considerada como uma vitória do movimento municipalista que havia se organizado logo após a renúncia do Presidente Collor, dentro de um espírito nacional de expectativa de avanço democrático e de reformulação do aparelho do Estado. A edição dessa norma 
fez-se acompanhar de documento denominado "A Ousadia de Cumprir e Fazer Cumprir a Lei", elaborado em conjunto com representações dos conselhos de saúde estaduais e municipais e representantes da sociedade civil, que continha um diagnóstico do modelo assistencial brasileiro e indicava as mudanças necessárias ${ }^{8}$.

A relevância da NOB 01/93 foi a de reconhecer que estados e municípios são gestores do SUS e não prestadores dos serviços de saúde e instituir o mecanismo de transferência de recursos pela modalidade "fundo a fundo", além dos fóruns de negociação entre os gestores federais, estaduais e municipais, denominados Comissão Intergestores Tripartite (CIT) e Comissão Intergestores Bipartite (CIB). ${ }^{9}$

A NOB-SUS $01 / 96^{10}$ aprofundou os avanços da norma anterior. Sob o tema "Gestão Plena com Responsabilidade pela Saúde do Cidadão", apresentou como diretriz a responsabilização do governo municipal como gestor do sistema de saúde, assumindo as "funções de coordenação, articulação, negociação, planejamento, acompanhamento, controle, avaliação e auditoria"11. Definiu a esfera estadual como mediadora da relação entre os sistemas municipais de saúde e a esfera federal como mediadora das relações entre os sistemas estaduais ${ }^{12}$.

Nas Comissões Bipartite e Tripartite, os gestores dos entes federados passaram a pactuar a programação das atividades de assistência ambulatorial e hospitalar, de vigilância sanitária e de epidemiologia e controle de doenças (Programação Pactuada e Integrada - PPI), o que tornou possível caminhar na direção de uma integração efetiva dos sistemas locais de saúde.

A PPI traduzia as responsabilidades de cada município pela garantia de acesso da população aos serviços de saúde, quer pela oferta dos serviços do próprio município, quer pelo encaminhamento a outros municípios, por intermédio das relações entre os gestores municipais, mediadas pelo gestor estadual (SANTOS e ANDRAdE, 2007). Outro aspecto relevante da NOB 01/96 foram os mecanismos e fluxos de financiamento por ela introduzidos, que reduziram, progressivamente, a remuneração dos municípios por serviços prestados e ampliaram as transferências de caráter global - fundo a fundo - com base nas programações pactuadas e integradas dos serviços de saúde.

Dadas as grandes diferenças regionais e locais, tanto em termos de infraestrutura de atenção à saúde como de capacidade de gestão das unidades federadas e dos municípios, criou-se uma classificação da gestão estadual, com base no grau de assunção das responsabilidades de cada ente, utilizando-se os conceitos de gestão avançada ou plena.

Apesar dos indiscutíveis avanços alcançados com a NOB-SUS 01/96 em direção à descentralização, podem ser constatados alguns problemas de natureza conjuntural e estrutural. Em primeiro lugar, a exigência de o município se habilitar à gestão avançada ou plena para fazer jus às transferências de recursos da União alijou do Sistema os municípios de pequeno porte - sem condições de assumirem a gestão plena de seu sistema municipal - do mecanismo de transferência fundo a fundo. Houve dificuldades de organização dos sistemas de saúde municipais, pela baixa funcionalidade dos pactos que se estabeleceram entre estados e municípios no que se refere à divisão de responsabilidades entre eles e de gestão das unidades de saúde. Além disso, a bipolaridade imposta à habilitação ao sistema - gestão plena ou avançada - 
levou muitos municípios a se habilitarem como gestão plena, embora não tivessem as condições para isso.

As Normas Operacionais de Assistência à Saúde (Noas) ${ }^{13}$, que sobrevieram à NOB 01/96, aprofundaram o processo de descentralização da gestão do SUS, ao introduzirem o processo de regionalização como estratégia de hierarquização dos serviços. Adotou-se a lógica do planejamento integrado, com base no conceito de território, na conformação dos sistemas funcionais de saúde - não necessariamente restritos aos municípios, ainda que respeitados os seus limites como unidade indivisível -, na perspectiva de assegurar aos cidadãos acesso a todas as ações e serviços de saúde, além de otimizar os recursos.

Foi instituído o Plano Diretor de Regionalização (PDR) dos serviços de assistência à saúde em cada estado e no Distrito Federal, que organizou o território dos estados em regiões ou microrregiões e módulos assistenciais, além da conformação de redes hierarquizadas de serviços e o estabelecimento de mecanismos e de fluxos de referência intermunicipais ${ }^{14}$.

Os serviços e ações de saúde classificados como de média complexidade ficaram ao encargo dos âmbitos microrregionais, regionais ou estaduais do SUS, enquanto que a garantia de acesso da população aos serviços de alta complexidade foi definida como responsabilidade solidária da União e dos estados. Os gestores estaduais foram responsabilizados pela gestão da política de alta complexidade em cada estado; e ao Ministério da Saúde cumpriu definir o financiamento das ações de alta complexidade e das ações estratégicas para cada estado. ${ }^{15}$

Destaca-se a inovação da Noas-SUS 2002, que adotou o modelo de contratação de resultados no ambiente hospitalar, por meio de instrumento do gênero do contrato de gestão, para remunerar os hospitais públicos subordinados ou vinculados a uma esfera de governo, sob a gestão de outro ente federado. Esse foi o caso dos hospitais federais nos estados, cujas relações com o gestor estadual passou a se dar com base em metas estabelecidas de comum acordo e não mais pelo sistema de produção. No plano do financiamento, registre-se o avanço introduzido pela Emenda Constitucional no 29 , aprovada em 2002, que assegurou o financiamento compartilhado da União, dos estados e dos municípios, além da destinação, para a saúde pública, de um volume maior de recursos ${ }^{16}$.

Ainda que as sucessivas normas do Executivo Federal tenham contribuído para direcionar o Sistema a um modelo de articulação federativa consensual e a uma política de financiamento baseada quase que exclusivamente no critério de produção de serviços, projetos e programas, constatouse haver um esgotamento no modelo de regulação exaustiva do Ministério da Saúde (via NOBs), que transformava estados e municípios em gestores de projetos e programas federais.

Assim, em 2006, no âmbito do Pacto pela Saúde ${ }^{17}$, foi iniciado um conjunto de reformas institucionais do SUS, pactuado entre as três esferas de gestão, que substituiu os processos de habilitação de estados e municípios à participação na rede e vinculou o financiamento a metas e compromissos para cada ente da federação, dando maio foco no alcance de resultados (Portal do Ministério da Saúde, 2009), como se depreende do seu texto de introdução:

"O Sistema Único de Saúde (SUS) é uma política pública que acaba de completar uma década e meia de 
existência. Nesses poucos anos, foi construído no Brasil um sólido sistema de saúde que presta bons serviços à população brasileira. O SUS tem uma rede de mais de 63 mil unidades ambulatoriais e de cerca de 6 mil unidades hospitalares, com mais de 440 mil leitos. Sua produção anual é aproximadamente de 12 milhões de internações hospitalares; 1 bilhão de procedimentos de atenção primária à saúde; 150 milhões de consultas médicas; 2 milhões de partos; 300 milhões de exames laboratoriais; 132 milhões de atendimentos de alta complexidade e 14 mil transplantes de órgãos. Além de ser o segundo país do mundo em número de transplantes, o Brasil é reconhecido internacionalmente pelo seu progresso no atendimento universal às Doenças Sexualmente Transmissíveis/Aids, na implementação do Programa Nacional de Imunização e no atendimento relativo à atenção básica. O SUS é avaliado positivamente pelos que o utilizam rotineiramente e está presente em todo território nacional.

Ao longo de sua história, houve muitos avanços e também desafios permanentes a superar. Isso tem exigido, dos gestores do SUS, um movimento constante de mudanças, pela via das reformas incrementais. Contudo, esse modelo parece ter se esgotado, de um lado, pela dificuldade de imporem-se normas gerais a um país tão grande e desigual; de outro, pela sua fixação em conteúdos normativos de caráter técnico-processual, tratados, em geral, com detalhamento excessivo e enorme complexidade.

$\mathrm{Na}$ perspectiva de superar as dificuldades apontadas, os gestores do SUS assumem o compromisso público da construção do Pacto pela Saúde 2006, que será anualmente revisado, com base nos princípios constitucionais do SUS, ênfase nas necessidades de saúde da população, e que implicará o exercício simultâneo de definição de prioridades articuladas e integradas nos três componentes: Pacto pela Vida, Pacto em Defesa do SUS e Pacto de Gestão do SUS.
"A descentralização só ocorre de fato quando o poder central abre mão do seu papel de controlador e assume a coordenação, descentralizando, também, a autonomia de gestão para os entes subnacionais."
Estas prioridades são expressas em objetivos e metas no Termo de Compromisso de Gestão e estão detalhadas no documento Diretrizes Operacionais do Pacto pela Saúde 2006." $" 18$

A análise da experiência nacional de implantação do SUS evidencia alguns pontos relevantes que merecem ser 
enfatizados. Em primeiro lugar, deve-se reconhecer a importância política das estruturas de governança participativas do Sistema, em especial da Conferência Nacional de Saúde, que se reúne a cada quatro anos, com representação de vários segmentos sociais, com a finalidade de avaliar a situação de saúde e propor diretrizes para a formulação da política de saúde nos níveis correspondentes, com possibilidade de convocação extraordinária pelo Conselho de Saúde.

A estrutura deliberativa do SUS prevista na Lei $\mathrm{n}-8.080 / 90$ supera o modelo decisório autocentrado, característico da burocracia brasileira, e inova ao adotar, na implantação das políticas públicas de saúde, um sistema de liderança participativo e democrático. Os conselhos de saúde, presentes nos entes federados, na qualidade de órgãos colegiados e permanentes, viabilizaram a participação dos representantes governamentais, prestadores de serviços, profissionais da saúde e usuários nos processos de formulação de estratégias e controle da execução da política de saúde, no qual as decisões tomadas em consenso eram posteriormente homologadas pelo chefe do Poder Executivo, em cada esfera de governo. ${ }^{19}$

Os conselhos de saúde constituíramse nos pilares centrais da organização e funcionamento do SUS, especialmente no que se refere à participação coordenada dos atores sociais e à mobilização crescente de novos atores que surgiram a partir descentralização, com papel decisivo no processo de municipalização das questões de saúde.

Importante registrar que, em um país com acentuado nível de exclusão e desigualdade social e uma passividade histórica do grande conjunto da sociedade em relação à atividade estatal, as instâncias participativas do SUS constituem mecanismos educativos, de indução à participação cidadã nos processos de gestão de políticas públicas.

Outro aspecto relevante é o modelo de planejamento adotado pelo Sistema Único de Saúde, que rompeu com a tradição do planejamento de cima para baixo e privilegiou a elaboração do plano, a partir das demandas sociais do município e da capacidade estatal de atendimento na região. O planejamento regionalizado, de baixo para cima, ordenado por meio da Programação Pactuada Integrada, articulado pelo gestor municipal, transcendeu, a um só tempo, as fronteiras do planejamento burocrático de gabinete e as fronteiras do município, promovendo a cooperação intermunicipal.

$\mathrm{Na}$ área do financiamento das ações de saúde, destacam-se importantes evoluções, tais como a adoção do sistema de transferências intergovernamentais de recursos financeiros fundo a fundo, em substituição à estrutura convenial, herdada do Programa dos Sistemas Unificados e Descentralizados de Saúde (SUDS), que vigorou até 1991. Com base em critérios de alocação definidos na Lei no ${ }^{\circ} 8.080 / 90$, os recursos do Fundo Nacional de Saúde passaram a ser transferidos de forma regular e automática diretamente para os fundos estaduais e municipais. Embora 60\% dos serviços de saúde atualmente prestados estejam sob o encargo dos municípios, no mínimo 50\% dos recursos que financiam toda a saúde pública nacional tem origem federal.

A substituição do modelo de financiamento convenial pelo negocial foi decisiva para a maturidade do SUS, ao viabilizar a definição negociada, no âmbito de uma Comissão Intergestores Tripartite, dos valores do financiamento a partir das especificidades e magnitude de cada demanda local. A remuneração de 
serviços e atendimentos em regime de contraprestação, de acordo com tabela de valores de procedimentos estabelecidos pela Direção Nacional do SUS, tem contribuído para a internalização dos paradigmas da gestão por resultados na área da saúde e para a transparência das ações do Sistema.

Santos \& Andrade (2007) afirmam que o SUS reúne todos os elementos que caracterizam a nova gestão pública:

a) a descentralização administrativa para os entes subnacionais, com empoderamento dos municípios como os principais gestores da política pública de saúde;

b) a constituição das instâncias decisórias que contemplam a participação do usuário e do cidadão;

c) a parceria com o setor privado e social na implantação dos serviços de saúde, com fortalecimento das funções estatais de regulação, fiscalização e controle;

d) a valorização do cidadão-usuário como foco na concepção das políticas de saúde;

e) a transparência da gestão;

f) o financiamento multilateral, com compartilhamento de responsabilidades e decisões consensuais; e

g) o funcionamento em rede, que congrega entes estatais das três esferas, sociedade civil, entidades empresariais e o cidadão.

Sem embargo dos avanços obtidos com o modelo de articulação federativa na prestação de serviços públicos de saúde, ainda existem obstáculos e novos desafios a serem vencidos. Um deles é a falta de sintonia entre a descentralização das atividades de saúde e a atual estrutura tributária, que faz com que $60 \%$ dos serviços de saúde estejam sob a responsabilidade dos municípios e que 50\% dos recursos aplicados nesses serviços sejam oriundos da União.
Outro desafio refere-se à necessidade de investir em mecanismos de qualificação da representação dos setores sociais nos conselhos de saúde, assim como de capacitação dos conselheiros, mitigando o papel da autoridade sanitária frente ao papel da sociedade ali representada.

Aspecto fundamental à moderna concepção administrativa e técnica do SUS é a geração de novos arranjos institucionais e administrativos sintonizados com o princípio da descentralização, da participação social e da gestão de resultados. Os institutos públicos atuais, regulados pelo Decreto-lei no 200/67, foram constituídos sob paradigmas que o SUS visou superar - o da centralidade política administrativa e o da submissão social ao poder da autoridade pública, características essenciais do período de ditadura militar. Nesse aspecto, é preciso redesenhar as figuras jurídicas da administração pública, de forma a dotá-las de mecanismos de governança abertos à participação social; à parceria públicoprivada na consecução de objetivos públicos; ao monitoramento e à avaliação social dos resultados obtidos pela ação pública, em especial no que se refere à sua efetividade; às novas relações federativas de compartilhamento de responsabilidades.

Embora seja um processo em curso, é indiscutível que o SUS representa uma experiência inédita e exitosa de organização da prestação de serviços de saúde integral, reunindo em um único sistema de abrangência nacional os serviços prestados em 27 unidades da federação e mais de 5.500 municípios, no contexto de uma grande diversidade de realidades em termos de perfil socioeconômico da população, de características ambientais e de perfil epidemiológico, característico de um país de dimensões continentais. 


\section{A articulação na assistência social - um modelo em construção}

O processo histórico de desenvolvimento do assistencialismo no Brasil, estreitamente vinculado ao de Portugal, conformou-se pela influência determinante de práticas de caridade, de natureza voluntária e eventual, com participação determinante da Igreja e das instituições de natureza filantrópica, em reflexo ao conservadorismo da sociedade elitista no acesso às riquezas sociais. Desde o século XVII, a associação da filantropia com a caridade na assistência social fundamentouse no pensamento de que os "desvalidos da sorte" não eram merecedores da atenção do Estado, apenas da benevolente ajuda ao próximo de pessoas caridosas das elites dominantes e da Igreja.

A ausência histórica do Estado na assistência social permitiu a constituição de instituições de grande porte vinculadas, na maioria absoluta dos casos, às igrejas. Artigo publicado na Revista Veja (edição especial de dezembro de 2001) de autoria de Antonio Milena, mostra que "bá entidades filantrópicas com estrutura maior que a de algumas grandes empresas". Segundo o artigo, a Pastoral da Criança tem um quadro de voluntários de 150 mil pessoas, o que, conforme o autor, é mais que o total de metalúrgicos em todo o país, responsável pela prestação de serviços a 1,5 milhão de pessoas. Outras entidades citadas são a Associação de Assistência à Criança Deficiente (AACD), que, embora com quadro menor de voluntários, arrecada mais de $\mathrm{R} \$ 40$ milhões, e o Grupo de Apoio ao Adolescente e às Crianças com Câncer (Graacc), que movimenta, segundo o artigo, $\mathrm{R} \$ 12$ milhões por ano, muito mais que a seção brasileira da "Médicos Sem Fronteiras". Ao final, o artigo apresenta quadro das movimentações financeiras anuais das principais entidades civis que atuam na área social no país, algumas delas há mais de 40 anos, como as Apaes (46 anos); a AACD (51 anos); a Visão Mundial (26 anos); o Fundo Cristão para Crianças (35 anos); as Aldeias Infantis SOS (34 anos); o Grupo de Apoio ao Adolescente e à Criança com Câncer (34 anos), além da Cáritas Brasileira (45 anos) que, juntas, são responsáveis por uma movimentação superior a $R$ \$ 344,5 milhões por $\mathrm{ano}^{20}$.

$\mathrm{Na}$ Constituição Federal de 1988, a assistência social foi abordada como um direito social, independente da previdência social, embora a implementação desse direito tenha se revelado um processo complexo, em função da forte influência conservadora e da tradição do voluntariado, especialmente de fundo religioso, no desenvolvimento das atividades assistenciais.

Os primeiros anos pós-constituinte refletiram a contradição entre os setores conservadores, que pretendiam a manutenção do assistencialismo tradicional, e os setores sociais, que haviam imposto a assistência social como um direito social. Houve, no entanto, importantes conquistas, como a da aprovação da Lei no ${ }^{\circ} 8.742$, de 7 de dezembro de 1993, denominada Lei Orgânica da Assistência Social (Loas).

A lei reconhece que a assistência social é um "direito do cidadão e um dever do Estado" e tem os objetivos de proteger a família, a maternidade, a infância, a adolescência e a velhice, com especial atenção ao amparo de crianças e adolescentes carentes; à integração do cidadão ao mercado de trabalho; à habilitação e reabilitação de pessoas portadoras de deficiência e ao apoio financeiro ${ }^{21}$ a essas e aos idosos sem meios de prover sua manutenção.

O marco legal ressalta a universalização dos direitos sociais; a supremacia 
do atendimento às necessidades sociais sobre as exigências de rentabilidade econômica e o respeito à dignidade do cidadão, à sua autonomia e ao seu direito a benefícios e serviços de qualidade, vedada qualquer comprovação vexatória de necessidade.

Os serviços assistenciais são constituídos pelas atividades continuadas que visem à melhoria de vida da população e cujas ações são voltadas para as necessidades básicas ${ }^{22}$. Os programas são destinados prioritariamente às ações de inserção profissional e social. Já os projetos envolvem o enfrentamento da pobreza.

A realização da assistência social no Brasil, por previsão legal, observa as diretrizes da descentralização políticoadministrativa para os entes federados; do comando único das ações em cada esfera de governo; da participação da população nos processos de formulação das políticas e no controle das ações, em todos os níveis; e da primazia da responsabilidade do Estado na condução da política de assistência social, em cada nível de governo.

Reflete, portanto, as diretrizes gerais impostas pela Constituição Federal à seguridade social, tal qual a legislação do Sistema Único de Saúde, sendo que, em seu art. $6^{\circ}$, institui o sistema de assistência social, também à semelhança da legislação do SUS:

"As ações na área de assistência social são organizadas em sistema descentralizado e participativo, constituído pelas entidades e organizações de assistência social abrangidas por esta lei, que articule meios, esforços e recursos, e por um conjunto de instâncias deliberativas compostas pelos diversos setores envolvidos na área."
Em seu art. 11, a LOAS estabelece as competências gerais das três esferas de governo:

"Art. 11. As ações das três esferas de governo na área de assistência social realizam-se de forma articulada, cabendo a coordenação e as normas gerais à esfera federal e a coordenação e execução dos programas, em suas respectivas esferas, aos estados, ao Distrito Federal e aos municípios”.

No rastro do modelo adotado pelo SUS, a regulamentação da lei e a organização da estrutura sistêmica de assistência social no país adotaram o procedimento de emissão de normas operacionais pelo Poder Executivo Federal. A Norma Operacional editada em 1997 versou sobre a estrutura das ações de assistência social, composta por serviços, programas e projetos. A Norma Operacional do Gestor Federal de 1998 definiu as atribuições dos conselhos de assistência social e criou os espaços de negociação e pactuação - Comissões Intergestora Bipartite e Tripartite, com representações municipais, estaduais e federal de assistência social. O Sistema Único de Assistência Social (Suas) foi implantado em 2005, após evento do Conselho Nacional de Assistência Social, que congregou gestores e assistentes sociais de todo o país, embora sem institucionalização legal.

São muitos os pontos de semelhança entre os marcos legais do Suas e do SUS, a exemplo da estrutura de participação e controle social organizada com base em conselhos municipais, estaduais e nacional. O Fórum Nacional de Secretários Estaduais de Assistência Social (Fonseas) e o Colegiado Nacional de Gestores Municipais de Assistência Social (Congemas) são 
entidades igualmente importantes na articulação federativa no contexto do sistema nacional e descentralizado de assistência social.

Um aspecto que distingue a assistência social das outras áreas da seguridade é a previsão constitucional de que as entidades beneficentes e de assistência social são executoras das políticas públicas de assistência social junto a estados e municípios, reservada a coordenação e a edição de normas à esfera federal. A Loas estabelece que as ações de assistência realizadas no âmbito das entidades e organizações de assistência social devem observar as normas expedidas pelo Conselho Nacional de Assistência Social (CNAS) e que o funcionamento das organizações depende de prévia inscrição no respectivo conselho municipal ou estadual, conforme o caso, a quem cabe também a fiscalização dessas organizações (arts. 7ํ e 9, respectivamente).

Em favor dessas instituições, a Constituição Federal de 1988 dispõe sobre a isenção da contribuição previdenciária ${ }^{23}$ e veda a instituição de impostos sobre patrimônio, renda e serviços de partidos políticos, inclusive suas fundações, das entidades sindicais dos trabalhadores, das instituições de educação e de assistência social, sem fins lucrativos, atendidos os requisitos da lei.

A inscrição nos conselhos de assistência social é condição para a obtenção do certificado de entidade beneficente de assistência social junto ao Conselho Nacional de Assistência Social (CNAS). No âmbito do sistema, a relação entre o poder público e as entidades beneficentes e organizações é pactuada pelos estados e municípios, por meio de convênios.

Diferentemente da educação e da saúde, a Constituição ${ }^{24}$ e a lei não estabeleceram vinculações de receitas tributárias para o custeio da assistência social, embora tenham previsto a renuncia fiscal em favor das entidades que atuam no setor, por meio da imunidade previdenciária. Os recursos públicos para financiamento da assistência social são oriundos das mesmas fontes de custeio da seguridade social em geral, definidos nos orçamentos da União, dos estados e dos municípios. As transferências de recursos financeiros da União para os demais níveis de governo são realizadas pelo Fundo Nacional de Assistência Social para os fundos estaduais e municipais de assistência, cuja existência é requisito para o recebimento de recursos da União.

A respeito dos programas sociais desenvolvidos no âmbito do Suas, de maior impacto e relevância no país, devese mencionar o programa de renda mínima Bolsa Família. Esse programa tem uma história particular e uma estrutura especial $^{25}$ que revelam a sua importância na promoção da cidadania no país. Em suas origens, a iniciativa governamental era denominada Programa de Renda Mínima, gerenciado pelo órgão federal responsável pela área de assistência social. Naquela época, seu objetivo principal era prestar apoio ao desenvolvimento de programas municipais de renda mínima, operacionalizado por meio de convênios.

A Lei federal $\mathrm{n}^{\mathrm{O}}$ 10.219, de 2001, transformou a a iniciativa no Programa Nacional de Renda Mínima Bolsa Escola e transferiu sua gestão para o Ministério da Educação. O Bolsa Escola tinha como objetivo prestar apoio às famílias carentes com filhos em idade escolar, com vistas à permanência na escola. Em seu novo formato, o programa deixou de prestar apoio a iniciativas municipais de assistência para se tornar um programa de assistência federal, diretamente ao cidadão, ainda que sua implementação tenha se dado em articulação com os municípios, no que se refere ao cadastramento 
das famílias e seu acompanhamento, além do controle da frequência escolar das crianças. O custeio e o pagamento dos benefícios do programa, de responsabilidade federal, eram realizados mediante o apoio operacional da Caixa Econômica Federal.

A Lei no 10.836 , de 2004, criou o Bolsa Família, que aglutinou, em uma só estratégia, os programas de transferências de renda do governo federal, especialmente o Bolsa Escola, o Programa Nacional de Acesso à Alimentação (PNAA), o Bolsa Alimentação do Ministério da Saúde e o Auxílio-Gás, unificando sua gestão e execução. A operacionalização do novo programa observou as mesmas aplicadas anteriormente ao Bolsa Escola, ou seja, execução financeira no âmbito federal, por meio da Caixa Econômica e parceria com estados e municípios, responsáveis pelo cadastramento e acompanhamento das famílias.

Interessante destacar que, em razão do processo histórico de surgimento e evolução do programa no país, as relações federativas estabelecidas no Programa Bolsa Familia distinguem-se daquelas estabelecidas no Sistema Único de Assistência Social. Nesse caso, não houve a descentralização de recursos para estados e municípios - à exceção de pequeno percentual, aprovado recentemente, destinado especificamente ao custeio de atividades administrativas dos municípios relacionadas com responsabilidades legais no programa.

Os benefícios são pagos com recursos diretos da União, por meio de agente financeiro federal, como alternativa para superar o atual modelo de transferências por meio de convênios, que constitui forte entrave burocrático. A parceria estabelecida pelo governo federal diretamente com os municípios brasileiros, sem envolver transferência de recursos financeiros, viabilizou a implantação do programa em curto espaço de tempo. Nada indica, entretanto, que as relações federativas desenvolvidas no Bolsa Família não possam evoluir no sentido de uma maior descentralização, em vista, inclusive, das recentes medidas do governo federal no sentido de um maior apoio e fortalecimento da gestão da parte municipal do programa, o que pode ser indicativo de tendência nessa direção.

\section{$O$ processo de reformas da administração pública para a gestão descentralizada de políticas públicas}

A Constituição Federal de 1988 pode ser considerada, sob o ponto e vista político e jurídico, como marco nacional da retomada do processo de democratização brasileira. Resultado dos movimentos e das lutas sociais em resistência à ditadura militar, o texto constitucional reconheceu os direitos sociais difusos e restabeleceu, no federalismo, o equilíbrio dos núcleos de poder, essenciais ao exercício democrático. Constituiu, a um só tempo, novo pacto social e novo pacto federativo.

Os arts. $1^{\circ}$ e 18 da Constituição traduzem uma opção inequívoca pelo fortalecimento do ente municipal, com categórica explicitação do município na composição da Federação - o que sinaliza, de forma emblemática, a opção nacional do processo constituinte em inverter o movimento expansionista do poder central para a ampliação do campo autonômico do município (Pires e Nogueira, 2009).

É preciso ponderar, no entanto, que às conquistas constitucionais auferidas não houve o necessário e adequado investimento na construção de um novo modelo de administração pública, sintonizado com os paradigmas da participação social; da atuação estatal em redes; da parceria 
público-privada e da autonomia dos entes federados. A máquina estatal, confrontada às mudanças político-administrativas promovidas pela Constituição - seja em relação à recuperação da autonomia administrativa dos estados e municípios e do seu fortalecimento, seja no âmbito das políticas sociais aliada às conquistas sociais -, reagiu com a mesma lógica e mecanismos desenvolvidos durante o regime militar, para a implementação da estratégia nacional desenvolvimentista. A estrutura da "administração para o desenvolvimento", concebida pelos governos militares estava voltada eminentemente para o plano econômico, conformada sob a visão autoritária da ditadura, com foco no Poder Executivo Federal, enquanto a área social encontrava-se carente e subdesenvolvida, em situação inversa à dos países desenvolvidos, onde a presença estatal nos setores sociais era relevante ${ }^{26}$.

A fragilidade estrutural das áreas de políticas públicas e gestão governamental comprometeu o processo de descentralização federativa e tornou essencial a promoção de uma ampla reforma do Estado e da administração, que investisse, especialmente, na estruturação de uma burocracia pública de natureza estratégica, capacitada para a gestão de políticas públicas e absorção de inovações gerenciais orientadas para uma administração para resultados.

Nessa perspectiva, em dezembro de 1994, foi apresentado à equipe de transição do governo recém-eleito naquele ano, o documento denominado "Reforma do Estado e Administração Pública: Diagnóstico e Propostas para o Novo Governo", elaborado por um grupo de servidores da carreira de Especialista em Políticas Públicas e Gestão Governamental, criada em 1989. O documento definia as características centrais do Estado democrático, determinantes para uma reforma da administração - a) Estado articulador de estratégias para o desenvolvimento; b) Estado supridor de serviços sociais básicos; c) Estado promotor de políticas públicas em articulação com os níveis estadual e municipal; d) Estado negociador dos processos de integração econômica regional e mundial -, e recomendava a adoção de uma série de mudanças na estrutura de organização e funcionamento da administração pública.

Relativamente ao setor de prestação de serviços sociais básicos e à promoção de políticas públicas em articulação com as esferas estaduais e municipais, o documento enfatizava:

"O Estado deverá estar voltado essencialmente para o suprimento das necessidades sociais de grandes parcelas marginalizadas da população, incluindo a geração de emprego e renda, bem como a prestação de serviços sociais básicos de boa qualidade nas áreas de saúde, educação, previdência e assistência social, habitação, saneamento básico, transportes coletivos, segurança etc.

Novos formatos e estilos de organização e gerência deverão ser experimentados, com vistas à busca da qualidade e de padrões confiáveis de gestão através do estímulo à participação da sociedade, particularmente, através das clientelas beneficiárias desses serviços, devendo se esperar delas uma atuação fiscalizadora e, sempre que possível, a atribuição de responsabilidades de cogestão desses serviços, mediante institucionalização de instâncias de participação.[...]

[...] O novo Estado deverá encontrar uma adequada tradução administrativa 
e institucional do sistema federativo definido na Constituição de 1988. À União caberá um papel predominantemente de formulação e implementação de políticas públicas, prestação de assistência técnica, normatização e regulação no âmbito nacional, e financiamento com finalidades compensatórias. Aos estados e municípios serão atribuídas as responsabilidades de execução direta e custeio dessas políticas. A nova configuração desse pacto federativo exigirá reformas constitucionais que explicitem os respectivos papéis, bem como os meios para tanto reservados."

A implementação do Sistema Único de Saúde e a promulgação da Lei Orgânica da Assistência Social determinavam urgentes mudanças no campo administrativo, com o desenho de novos institutos públicos que pudessem apoiar as novas relações entre os diversos agentes de ambos os sistemas. O novo contexto político-institucional exigia a presença de quadros estratégicos, dotados de profissionais qualificados, com sensibilidade social e visão política, além de capacidade para lidar com novos e modernos instrumentos de gestão e com as novas tecnologias de informação e comunicação que aceleradamente ganhavam espaço no setor público.

Sem a clara compreensão do novo papel do Estado, em todos os seus níveis de atuação, e da nova repartição de competências entre as esferas federal, estadual e municipal, o processo de descentralização encontrou resistências dentro da burocracia e obstáculos administrativos. Urgia substituir o modelo de administração centrada no planejamento econômico e com características tecnocráticas por uma gestão governamental democrática, capacitada para os processos participativos de formulação, implementação e avaliação de políticas públicas.

O diagnóstico contido no documento apresentado pelos gestores governamentais postulava em direção à necessidade de "um planejamento flexível, ágil, comprometido com a ação, que deverá ser também democrático e transparente, institucional e tecnicamente aberto à participação democrática da cidadania. Mais que isso, o planejamento poderá ser poderosa ferramenta de indução da participação popular nas decisões de Estado". A Constituição havia institucionalizado um modelo de implantação de políticas públicas de ampla articulação, negociação e cooperação entre atores políticos e sociais, ao qual a administração pública deveria se adaptar.

O movimento de Reforma do Aparelho do Estado Brasileiro - empreendido no período de 1995 a 1998, no Governo do Presidente Fernando Henrique Cardoso - atendeu, em grande parte, às recomendações do diagnóstico apresentado pelos gestores governamentais. A primeira e mais importante medida adotada naquela época foi a definição de uma política de recursos humanos direcionada à composição de quadros estratégicos para as atividades de formulação, implementação e avaliação de políticas públicas e à gestão governamental democrática, a partir da retomada de concursos para carreiras de áreas estratégicas, que haviam sido interrompidos durante o Governo Collor, a exemplo da carreira de Especialista em Políticas Públicas e Gestão Governamental ${ }^{27}$.

Outra medida de relevo foi a edição da Emenda Constitucional no 19 , de 1998, que objetivou corrigir excessos do texto constitucional de 1988 que, escrito sob o clamor da liberdade democrática recém-conquistada, 
promoveu um engessamento do regime administrativo aplicável à administração pública direta e indireta, como reação à excessiva discricionariedade do Poder Executivo Federal durante o regime militar. A autonomia gerencial da administração havia sofrido, particularmente, com esse engessamento, visto que a submissão das entidades da administração indireta prestadoras de serviços sociais diretamente à população - ao regime administrativo próprio das entidades de direito público, concebido para a máquina burocrática do Estado, enrijeceu a gestão em todas as suas dimensões, notadamente na área de compras governamentais, da administração orçamentária e financeira e de recursos humanos. Também representou perda de capacidade executiva e de administração em setores em que a agilidade e a flexibilidade são determinantes para a qualidade e a tempestividade da oferta de serviços aos cidadãos. A Emenda Constitucional introduziu a possibilidade do regime de emprego plural dentro dos órgãos e entidades de direito público, o que foi, posteriormente, contestado e julgado inconstitucional, pelo Supremo Tribunal Federal, não pelo mérito da matéria, mas por ter havido vício no rito constitucional de aprovação do dispositivo na emenda ${ }^{28}$.

A Emenda Constitucional n ${ }^{\circ}$ 19/98 aprovou ainda dois dispositivos relevantes para o processo de descentralização e a participação democrática dos usuários na gestão dos serviços públicos. Foi dada nova redação para o art. 241 da Constituição, que autoriza os consórcios públicos para a gestão associada de serviços públicos, bem como a transferência total ou parcial de encargos, serviços, pessoal e bens vinculados a serviços transferidos para órgãos de outros entes da federação.
A figura do consórcio já constava da Lei $\mathrm{n}^{\circ}$ 8.080, de 1990, que regulamentou o SUS, mas sua aplicação encontrava resistências, dada a falta de previsão constitucional desse instituto de articulação entre os entes públicos. O instrumento do consórcio visa facilitar a articulação regional da prestação de serviços, mediante associação de municípios e, eventualmente, dos estados. A participação dos usuários também ganhou espaço no texto constitucional. Embora esse dispositivo, em particular, não tenha sido regulamentado, a dimensão da participação social no processo de formulação e avaliação de políticas públicas foi devidamente incorporada em leis específicas como as dos sistemas de saúde e assistência social.

O movimento de Reforma de 19951998 orientou-se no sentido de uma gestão por resultados, dotada de instrumentos flexíveis para a relação intrafederativa; da agilização dos fluxos financeiros e de informações. Introduziu-se, nessa época, a previsão constitucional da figura do contrato interno à administração com vistas à ampliação da autonomia gerencial, vinculada à obtenção de metas de desempenho ${ }^{29}$. Em 1999, a gestão por resultados foi também impulsionada por reformulação do sistema de planejamento governamental fundamentado na lógica da orçamentação por programas que, lamentavelmente, não se completou em razão da sobrevivência das estruturas departamentais tradicionais.

Do balanço obtido entre os avanços das propostas da Reforma do Aparelho do Estado e as reações contrárias da burocracia em relação aos novos institutos, verifica-se saldo positivo. Propor medidas que impliquem em mudanças culturais e que alterem o status quo das forças políticas e administrativas será sempre um desafio. 
À época, as proporções desse desafio ganhavam maiores contornos pelo fato de o país haver recém-saído de um governo autoritário e cuja população ainda não havia construído um espaço de segurança e capacidade crítica para avaliar a qualidade e a profundidade de algumas das principais propostas apresentadas pelo governo federal. Por sua vez, a média e a baixa burocracia, submissas durante a ditadura, assustaram-se com o discurso elitista da Reforma do Estado, voltado essencialmente para a qualificação de altos cargos e opuseram-se, com apoio das entidades de classe, aos projetos modernizantes.

Nada obstante, grandes conquistas foram alcançadas, especialmente no que concerne à descentralização e à cooperação intrafederativa. São exemplos: a implantação dos sistemas integrados que reúnem órgãos e entidades das três esferas de governo, na prestação de serviços diretos aos cidadãos; os mecanismos de gestão participativa gerados com a experiência do SUS; os modelos e instâncias de negociação e pactuação interfederativa; e as transferências "fundo a fundo". A situação exigiu soluções criativas e inovadoras para a viabilização da execução descentralizada de diversos programas federais, embora algumas tentativas de descentralização tenham fracassado ou demorado a se consolidar.

O convênio, na qualidade de mais importante - senão único - instrumento de transferência de recursos, de natureza formalista e burocrática, foi substituído, em alguns casos, por outros mais flexíveis e que permitiam um fluxo financeiro mais ágil e eficiente, como a alternativa adotada pelo Programa Bolsa Família. A relação federativa na prestação de serviços de educação substituiu o convênio pela figura do "repasse direto", nos casos dos programas de Alimentação Escolar -
PNAE (Merenda Escolar) e Dinheiro Direto na Escola (apoio à manutenção escolar $)^{30}$. Essas e outras experiências, implementadas em diversos ministérios da área social, permitiram a agilização das transferências intrafederativas; a regularidade nos fluxos financeiros e de informações; assim como a gradativa substituição de controles burocráticos pelos controles de resultados e pelo controle social, apoiado na crescente participação social na gestão das políticas.

\section{A título de conclusão}

À reconquista do federalismo brasileiro pela Constituição Federal de 1988, seguiuse lento, embora rico, processo de reordenamento político-adminstrativo das relações entre os entes da federação, caracterizado por movimentos alternados de avanços em direção à descentralização e recuos à recentralização - esses últimos determinados pelos traços do antigo centralismo decisório na União, consubstanciado por um sistema tributário que ainda mantém estados e municípios dependentes das transferências federais na implementação de grande parte das políticas públicas sociais.

Outra evidência do movimento centralizador é a compulsão normativa da esfera federal - observada nas experiências de descentralização - que, não raras vezes, extrapolou os seus espaços de regulamentação, especialmente em matérias de competência legislativa concorrente, como no caso da legislação sobre consórcios ou ainda na invasão da autonomia administrativa do estados e municípios, por meio da edição de normas infralegais de caráter geral, como na experiência de edição das Normas Operacionais Básicas do SUS. Embora as intenções sejam, 
frequentemente, louváveis, na direção da disposição exaustiva dos institutos legais e da padronização de entendimentos e soluções, essa compulsão inibe e prejudica a geração de estratégias customizadas aos contextos díspares, além de estimular apatia e submissão aos desígnios federais.

A esse respeito, Pires e Nogueira (2009) alertam que "na descentralização, impõese a defesa de certa flexibilidade dos arranjos institucionais, contratuais e dos processos e procedimentos para que possam responder às especificidades das experiências e dos contextos de sua aplicação, seja em razão da situação de cada município no quadro geral - e, então, amparado por sua autonomia -, seja integrado em microrregiões, aglomerações urbanas ou regiões metropolitanas, quando o interesse local deve ser harmonizado com o interesse regional, na delicada tensão das autonomias municipal e do Estadomembro".

Além disso, as experiências de descentralização já implementadas no país demonstraram que nem sempre a visão central dos problemas setoriais atende à realidade local. Nesse aspecto, é importante destacar que as estruturas lógicas sobre as quais se fundamentou a criação dos principais mecanismos e instrumentos da administração pública foram constituídas com base na percepção da realidade do nível central do Estado. Grande maioria dos institutos jurídicos e administrativos atualmente vigentes foi concebida em processos de discussão e definição conduzidos no âmbito federal, ainda que esses institutos incidam, igualmente, sobre as gestões públicas estaduais e municipais.

O reposicionamento do município no cerne da composição federativa, como o lócus primordial do contato direto com o cidadão brasileiro, torna imperativa a revisitação das antigas bases do regime administrativo aplicável ao aparelho do Estado - no que concerne às formas de atuação, aos mecanismos e aos instrumentos gerenciais, para a redefinição de conceitos e mecanismos à luz da gestão municipal.

Outra questão importante na análise do tema da descentralização federativa é a revisão ou a regulamentação das atribuições concorrentes previstas na Constituição Federal, fonte de indefinições na divisão de responsabilidades entre os entes, especialmente no atual contexto de atuação dos governos, de complexidade crescente das demandas sociais e econômicas e de incapacidade de atendimento do Estado. Essas indefinições, aliadas à estrutura concorrente de destinação dos recursos orçamentários para financiamento das diversas políticas públicas e à estrutura tributária centralizada, concorrem para que se instale um "jogo de empurra” entre as esferas de governo.

Frequentemente são invocadas a falta de qualificação dos quadros dos governos estaduais e municipais para a condução de políticas públicas, assim como a maior exposição dos governos subnacionais às práticas patrimonialistas e coronelistas do uso da máquina pública. Em alguns setores, registra-se, inclusive, certa reserva do governo federal na adoção de mecanismos mais flexíveis de transferência de recursos para as instâncias estaduais e municipais de governo, sob a alegação de não haver garantias da efetiva aplicação no objeto da transferência pelo poder público local. Embora possa haver nesse temor, em poucos casos, um fundo de verdade, o certo é que essas são argumentações típicas de quem quer reter poder, ao invés de avançar em direção ao entrelaçamento cooperativo na gestão de programas públicos. 
Quanto à qualificação das gestões estaduais e municipais, a experiência federal de formação de quadros profissionalizados demonstra que esse não é um desafio inalcançável. Basta que haja real interesse e investimento adequado em gestão de pessoas. A esse respeito pode-se citar, como um dos efeitos da descentralização, a importante reversão no tamanho dos quadros de servidores dos governos federais, estaduais e municipais, ao longo dos últimos 20 anos. Segundo dados apresentados pelo Instituto de Pesquisa Econômica Aplicada (Ipea), em 1987, do total de servidores públicos civis no Brasil, $25 \%$ eram federais, $50 \%$ eram estaduais e $25 \%$ eram municipais. Em levantamento realizado em 2006, constatou-se que o governo federal é responsável por $15 \%$ dos servidores, os estados por $35 \%$ e os municípios por $50 \%$, o que demonstra o fortalecimento da gestão pública municipal.

Os dados sinalizam para a necessidade de readequar o vetor de investimento estatal na constituição e formação profissional de seus quadros de pessoal, com ênfase na adoção de mecanismos que privilegiem as necessidades locais. A antiga prática de "importar" modelos e práticas gerenciais, ditadas pelo âmbito federal, precisa ser substituída por uma política de pessoal que respeite as diferentes realidades socioeconômicas desses entes.

Quando analisadas as experiências de descentralização exitosas no país - especialmente as três abordadas neste trabalho percebe-se que grande parte do sucesso obtido decorreu da geração de alternativas metodológicas para a gestão integrada da política pública, geradas de baixo para cima, a partir da constatação da necessidade da derrubada dos velhos institutos e da construção de novas relações.
Dentre as mais importantes inovações que foram introduzidas no campo institucional e nos métodos de gestão pública, pode-se citar a adoção dos mecanismos de conferências regionais e nacionais, com ampla participação de especialistas e da sociedade civil - eventos de mobilização e participação fundamentais para a avaliação dos serviços prestados pelo Poder Público em todos os níveis de governo -, e a construção da agenda para a formulação das políticas. As conferências já fazem parte da institucionalidade de várias áreas de governo como educação, saúde, assistência social, ciência e tecnologia e meio ambiente. Também os conselhos, consultivos ou deliberativos, ampliaram a participação da sociedade civil na formulação e no controle das políticas e ações governamentais, nos três níveis de governo, contribuindo decisivamente para o aprofundamento $\mathrm{da}$ democracia. As comissões intergestoras de negociação e pactuação aplicadas no SUS e no Suas constituem-se como outra contribuição inovadora na articulação federativa.

O planejamento regional adotado pela área da saúde revelou a importância do território para o planejamento governamental. O que antes era quase uma exclusividade das áreas de infraestrutura, com a evolução e aprimoramento da gestão cooperativa federativa de serviços públicos, mostrou-se essencial nas áreas sociais.

Houve também significativo avanço em direção à gestão para resultados, ainda que seja necessário continuar o investimento em competência técnica para a definição de objetivos, metas e indicadores. Dentro da experiência do SUS, constatou-se que o controle formal, centrado nos procedimentos e rotinas, não respondia às necessidades de uma eficiente prestação de serviços e ágil movimentação financeira 
intrafederativa. Adotaram-se o modelo negocial, com controle de resultados, e os mecanismos de controle social, menos burocráticos e mais efetivos.

Há várias lições aprendidas a partir das experiências de descentralização de políticas aqui analisadas - de educação, de saúde e de assistência social: a) o concerto federativo é possível e viável, embora a sua implementação seja lenta, com avanços e retrocessos naturais a qualquer processo que envolve alteração nos vetores de poder e mudança cultural e comportamental; b) a descentralização só ocorre de fato quando o poder central abre mão do seu papel de controlador e assume a coordenação, descentralizando, também, a autonomia de gestão para os entes subnacionais. A criação de fóruns de articulação, como os conselhos Nacional de Secretários de Administração (Consad) e de Secretários Estaduais de Planejamento (Conseplan), são passos importantes nesse sentido ${ }^{31}$; c) o empoderamento dos estados e municípios viabiliza a substituição das relações conveniais tradicionais, que preservam a posição dominante da esfera federal, pelas relações negociais, em que partícipes do acordo concertam, junto a atores sociais, as demandas locais e constroem um planejamento ascendente para a implementação da política pública, a partir das necessidades efetivas dos cidadãos; d) os modelos e ferramentas gerenciais aplicáveis a sistemas descentralizados de implantação de políticas públicas são radicalmente diferentes dos gerados para modelos hierárquicos e autoritários. Por isso, é essencial conceber novos institutos administrativos, adequados à ação coordenada de governo, em rede com os atores sociais; e) os fluxos de recursos financeiros, assim como os fluxos de informações, em todos os sentidos, constituem elemento fundamental da nova gestão intrafederativa. Os sistemas de informações envolvem necessariamente a cooperação federativa, seja na alimentação de dados dos sistemas estatísticos, como na produção de indicadores nacionais, regionais e locais. São reversões radicais nos paradigmas da administração pública brasileira - sintonizadas com os objetivos e princípios democráticos da Constituição Cidadã que precisam ser expandidas por sobre os demais institutos públicos.

É absolutamente necessário integrar a articulação federativa no conceito de administração pública. Vale aqui o aforismo de Nietzche ${ }^{32}$ : "A derrubada das opiniões não segue exatamente a derrubada das instituições. As novas opiniões foram por muito tempo à casa de suas antecessoras, agora desolada e sinistra até mesmo a preservam por falta de moradia”.

Apesar da moderna concepção administrativa e técnica do SUS, Suas e do Sistema Educacional Brasileiro, são necessários novos arranjos institucionais, administrativos e culturais. Os modelos de estruturação administrativa, de transferências de recursos vigentes estão assentados, ainda, na legislação da época da ditadura e precisam, o quanto antes, ser revistos sob os paradigmas democráticos da participação e controle social, da gestão por resultados e da descentralização federativa. A visão concentrada no Executivo Federal, herdada da cultura do regime militar, precisa ser superada. Não há mais como isolar a administração pública federal das demais esferas de governo. Os sistemas integrados de serviços públicos impõem um sistema de planejamento que nasce na base da sociedade, nos municípios, e sobe até a União, por meio dos novos mecanismos de planejamento setorial federativo, já 
implantados ou em processo de implantação, e que envolvem intensa participação social.

O novo contexto da administração pública exige a articulação efetiva dos órgãos responsáveis pela gestão pública nas três esferas de governo. Adquirem importância fundamental a assistência técnica e os investimentos federais voltados para a melhoria da capacidade de gestão de estados e, principalmente, dos municípios, os quais hoje já são responsáveis por grande parte da prestação de serviços nas áreas sociais.

São necessários mecanismos que promovam a articulação dos governos federal, estadual e municipal na formulação das normas para a administração pública das três esferas de governo e também a elaboração de propostas voltadas para a melhoria do desempenho da administração pública em todos os níveis, que respeite a autonomia dos entes e suas especificidades.

A reforma do Estado e a implementação do novo pacto federativo revela não só a necessidade de rever conceitos de administração pública, no sentido de compreendê-la como uma totalidade que envolve os três poderes da República e as três esferas de governo, mas também, no sentido da inseparabilidade entre fins e meios, entre as políticas públicas e os processos e instrumentos de gestão. A substituição da estrutura sistêmica atual, excessivamente especializada e segmentada, por um sistema integrado de políticas públicas e gestão governamental, ou simplesmente de gestão governamental, é uma reforma que clama por ser efetuada e constitui uma das tarefas urgentes para a administração pública.

(Artigo recebido em novembro de 2009. Versão final em março de 2010)

\section{Notas}

1 Conforme $\int 1^{\circ}$ do art. 211 da Constituição, com a redação dada pela Emenda Constitucional no 14 , de 1996 .

2 Registre-se que o ensino médio não é ainda obrigatório no Brasil. A Constituição definiu a obrigatoriedade e a gratuidade do ensino fundamental. No caso do ensino médio, foi definido apenas o objetivo de sua progressiva universalização e gratuidade, embora também tenha sido definida a gratuidade do ensino em qualquer estabelecimento oficial. A partir da EC $\mathrm{n}^{\circ}$ 14, de 1996, a educação infantil, dos quatro aos seis anos de idade, foi incorporada à estrutura da educação básica, deixando de ser considerada como pré-escolar.

3 Conforme art. 212 da Constituição Federal, cumpre à União aplicar percentual mínimo de $18 \%$ de suas receitas na área do ensino, enquanto que estados, o Distrito Federal e municípios ficam obrigados a aplicar o mínimo de $25 \%$ das receitas fiscais, excluídas dessa obrigatoriedade as receitas de contribuições sociais.

4 A criação do Fundef foi aprovada pela Emenda Constitucional no 14, de 1996.

5 O Fundo de Manutenção e Desenvolvimento da Educação Básica (Fundeb) foi criado em 2006, por meio da Emenda Constitucional noํ5, e substituiu o Fundef.

6 De acordo com o art. 16 da Lei no ${ }^{\circ} .080$, de 1990, compete à União formular as políticas nacionais; exercer a macrocoordenação do Sistema; elaborar normas relativas às diversas áreas de saúde; conceder apoio técnico e financeiro aos entes subnacionais no aperfeiçoamento de sua atuação; 
estabelecer normas e executar a vigilância sanitária em portos, aeroportos e fronteiras; estabelecer normas para regular as relações com a prestação de serviços privados ao SUS, além de fiscalizar e controlar os gastos com o apoio de uma auditoria criada por meio do Decreto n⿳⺈ 1.651, de 1995.

Registre-se a edição do Decreto ํㅡㄴ 1.651/95, que regulamenta o Sistema Nacional de Auditoria no âmbito do Sistema Único de Saúde; a Lei no 9.836/1999, que altera o Capítulo do Subsistema de Atenção à Saúde Indígena; a Lei no 10.424/2002, que dispõe sobre o Subsistema de Atendimento e Internação Domiciliar; e a Emenda Constitucional nº 29, de 13 de setembro de 2000, que assegura os recursos mínimos para o financiamento das ações e serviços públicos de saúde.

8 Em observância às propostas da Conferência Nacional de Saúde, criou-se no Ministério da Saúde um grupo com participação do Conselho Nacional dos Secretários de Saúde (Conass), Conselho Nacional dos Secretários Municipais de Saúde (Conasems) e outras entidades da sociedade civil, que foi responsável pela elaboração desse documento.

9 Ao amparo das NOB-SUS 01/93 e NOB-SUS 01/96, foram instituídas, ao lado dos conselhos de saúde, instâncias de negociação entre gestores das três esferas - a Comissão Intergestores Tripartite (CIT) e a Comissão Intergestores Bipartite (CIB), responsáveis pela pactuação da programação de serviços básicos, entre os gestores dos entes federados, assim como dos tetos financeiros aplicáveis a cada caso.

10 Aprovada pela Portaria n⿳ำ 2.203, de 2006, do Ministério da Saúde, a NOB 01 / 96 preocupavase em estabelecer a inversão do modelo de atenção à saúde centrado na responsabilidade do município pelo atendimento às necessidades e demandas de saúde e das exigências de intervenções saneadoras em seu território. A norma simplificou as modalidades de gestão e aprofundou o processo de descentralização, deixando explícitas as responsabilidades dos gestores estaduais e municipais (SANTOS \& ANDRADE, 2007). Preocupou-se, portanto, em propiciar condições para a construção da integralidade das ações e serviços de saúde, conciliando-os com políticas sociais e de infraestrutura, como moradia, renda, meio ambiente, entre outros. Tratou, ainda, da estruturação dos sistemas municipais de saúde; do papel articulador dos estados e da necessidade de reforçar o relacionamento intrafederativo; do papel da esfera federal, como gestora nacional do sistema; e da divisão de responsabilidade de financiamento entre as três esferas. Foi a primeira norma operacional a fazer referência ao reembolso das despesas por atendimentos em unidades públicas a beneficiários de planos de saúde.

11 Item 4 da Portaria/MS no 2.203 de 1996.

12 A norma falhou, no entanto, ao considerar como gestores apenas os municípios que se habilitaram no Sistema, dando aos demais o antigo tratamento de "prestadores de serviços" (SANTOS \& ANDRADE, 2007, pag. 65).

13 Após a NOB-SUS 01/96, foram editadas a Noas 01/2001 e a Noas 01/2002, respectivamente, pelas portarias GM-MS nº 95/2001 e nº 373/2002 do Ministério da Saúde.

${ }_{14}$ Passou-se, então, a existir a chamada Região de Saúde, que se constitui na base territorial de planejamento da atenção à saúde, definida pelas secretarias estaduais de saúde, em consonância com as especificidades e estratégias de regionalização em cada estado. O modelo de regionalização pode prever a divisão em macrorregiões, regiões e/ou microrregiões. Cada região pode compreender um ou mais módulos assistenciais. Dentro das regiões foram criados os munićpios-sede - habilitados em Gestão Plena do Sistema Municipal ou em Gestão Plena de Atenção Básica Ampliada - e municípios-pólo, que apresentam papel de referência para outros municípios, em qualquer nível de atenção. A constituição das regiões exige a qualificação dessas pela Comissão Intergestores Tripartite. Um conjunto mínimo de procedimentos de média complexidade - definido como primeiro nível de referência intermunicipal, com acesso garantido a toda a população no âmbito microrregional - é requisito para a qualificação de uma região de saúde. As microrregiões não qualificadas continuarão recebendo os recursos do SUS, na forma de pagamento por produção. 
15 As ações de média complexidade, excetuadas aquelas mínimas garantidas nos módulos assistenciais, passaram a ser asseguradas no âmbito microrregional, regional ou estadual de acordo com o Plano Diretor de Regionalização do Estado (PDR). O planejamento da oferta dos serviços de média complexidade a toda a população tornou-se objeto da Programação Pactuada e Integrada (PPI), coordenada pelo gestor estadual. Já a garantia de acesso da população aos serviços de alta complexidade ficou como responsabilidade solidária da União e dos estados.

16 A Emenda Constitucional no 29/2002 estabeleceu a vinculação de percentuais mínimos de suas receitas tributárias para estados e municípios. O montante da União, segundo a referida emenda, seria aprovado por meio de uma lei complementar. O art. 77 do Ato das Disposições Constitucionais Transitórias (ADCT) estabeleceu o percentual mínimo de 12\% para os estados e 15\% para os municípios. Dessa forma, ficou assegurado o financiamento compartilhado da União, dos estados e dos municípios e um volume maior de recursos. A lei complementar prevista no $\int 3^{\circ}$ do art. 198 , que fixará os percentuais definitivos, com revisão a cada cinco anos, ainda não foi aprovada. Continuam em vigor os percentuais constantes do ADCT.

17 O "Pacto pela Saúde 2006 - Consolidação do SUS” foi aprovado pela Comissão Intergestores Tripartite. Seu objetivo foi o "aprimoramento do processo de pactuação intergestores objetivando a qualificação, o aperfeiçoamento e a definição das responsabilidades sanitárias e de gestão entre os entes federados no âmbito do SUS", bem como a "definição de compromissos entre os gestores do SUS em torno de prioridades que apresentam impacto sobre a situação da saúde brasileira”. O pacto envolve três componentes: Pactos Pela Vida, em Defesa do SUS e, de Gestão. Portaria do Ministério da Saúde aprovou as Diretrizes Operacionais do Pacto que envolveram alterações em termos de prerrogativas e responsabilidades dos municípios e estados habilitados em Gestão Plena do Sistema, a partir da assinatura dos chamados Termos de Compromisso e Gestão a serem aprovados pelas respectivas instâncias de gestão.

18 Anexo I, Portaria/MS no 399, de 2006.

19 O Conselho Nacional de Saúde (CNS) tem representação do Conselho Nacional de Secretários Estaduais de Saúde (Conass) e do Conselho Nacional de Secretários Municipais de Saúde (Conasems).

${ }^{20} \mathrm{O}$ artigo da Revista Veja informa que as Apaes são responsáveis por movimentação de $\mathrm{R} \$ 200$ milhões/ano. A AACD tem movimentação anual de aproximadamente R\$ 43 milhões. A movimentação anual da Visão Mundial é de R \$ 26 milhões. O Fundo Cristão para Crianças tem movimentação de R $\$ 26$ milhões por ano. As Aldeias Infantis SOS tem um movimento de $\mathrm{R} \$ 15,5$ milhões / ano. O Grupo de Apoio ao Adolescente e à Criança com Câncer tem movimento anual de R \$ 12 milhões. Segundo o documento “Quem Somos" disponível no site da Cáritas Brasileira, a entidade tem uma movimentação de $\mathrm{R} \$ 7$ milhões. A Cáritas Brasileira foi fundada em 1956, pela CNBB, então sob a direção de Dom Hélder Câmara e teve como um de seus objetivos originais a coordenação da distribuição dos alimentos do Programa de Alimentos doados pelo Governo Norteamericano. Somente em 1966, entretanto, a Cáritas desligou-se do Secretariado da CNBB constituindose como entidade autônoma. Essa entidade teve seu papel reduzido ao longo do tempo, especialmente com o fim do Programa de Alimentos, e passou a redirecionar suas atividades para a construção da cidadania em articulação com as demais pastorais e com os movimentos populares.

21 A Loas definiu dois tipos de benefícios: de prestação continuada e o eventual. O benefício de prestação continuada é o da garantia de um salário mínimo mensal à pessoa portadora de deficiência e ao idoso com 70 anos ou mais, que comprovem não possuir meios de prover a própria manutenção e nem de tê-la provida por sua família, e é de responsabilidade da União. Já os benefícios eventuais - que visam ao pagamento de auxílio por natalidade ou morte às famílias cuja renda mensal per capita seja inferior a 1/4 do salário mínimo - foram atribuídos aos estados e municípios, 
que poderão aprovar outros, da mesma natureza, para atender necessidades advindas de situações de vulnerabilidade temporária, com prioridade para a criança, a família, o idoso, a pessoa portadora de deficiência, a gestante, a nutriz e nos casos de calamidade pública.

22 A Lei nº 11.258, de 2005, estabeleceu a inclusão nos serviços de assistência social de programas de amparo às crianças e adolescentes em situação de risco pessoal e social, em cumprimento ao disposto no art. $227 \mathrm{da}$ Constituição, bem como de amparo às pessoas que vivem situação de rua.

23 Conforme $₫ 70$ do art. 195: "São isentas de contribuição para a seguridade social as entidades beneficentes de assistência social que atendam às exigências estabelecidas em lei."

24 Vide Art. 198, \2º e Art. 212 da Constituição Federal.

25 A sua estrutura inclui um Conselho Gestor Interministerial do Programa Bolsa Família, vinculado à Presidência da República.

${ }_{26}$ Ressalta-se que o autor do presente artigo já em 1994, ao final do Governo Itamar Franco, já havia manifestado preocupação com a necessidade de mudanças na administração pública para o enfrentamento dos desafios democráticos e o novo pacto federativo, em documento publicado nos Cadernos da Escola Nacional de Administração Pública (ENAP) intitulado "Mudança de Governo: Propostas para uma Reforma Administrativa Democrática”, no qual assinalou:

"O Estado no Brasil tem hoje uma estrutura distorcida para o econômico. Por seu turno, a área social é extremamente carente e subdesenvolvida, o inverso do que ocorre nos países desenvolvidos onde o Estado tem uma grande presença na área social, própria das políticas públicas. A privatização de empresas não estratégicas para o desenvolvimento nacional deverá continuar na pauta dos próximos governos, assim como o fortalecimento das áreas sociais na estruturação do Estado". (ENAP Cadernos, volume 2, número 4, Reforma do Estado. Brasília, dezembro de 2004. página 97) "[...] Da mesma forma, a aceleração da descentralização constitui elemento fundamental para a democratização do Estado e a participação direta da sociedade civil na organização do poder público. Todos estes elementos permitirão, ao longo de um período de experiência democrática, um efetivo controle social sobre o Estado”. (Idem, pág. 99)

27 A carreira de Especialista em Políticas Públicas e Gestão Governamental (EPPGG), criada no primeiro governo da Nova República e interrompida no Governo Collor, foi retomada com a realização de concursos regulares para a renovação dos quadros superiores da administração e a superação da carência de quadros estratégicos de formação democrática. Atualmente, a carreira já conta com mais de 900 integrantes, formados pela Escola Nacional de Administração Pública (ENAP), em exercício em toda a administração direta, com boa presença nos ministérios das áreas sociais.

28 A adoção de um regime jurídico de trabalho específico para a atuação estatal nos setores de prestação de serviços sociais, que não exijam o exercício do poder de autoridade do Estado, é particularmente relevante, uma vez que as relações de trabalho unilaterais que se estabelecem no regime de trabalho estatutário aplicam-se, particularmente e exclusivamente, aos órgãos e entidades que funcionam sob o regime da hierarquia e de cujas atividades decorrem a geração ou a extinção de novos direitos e deveres para a sociedade como um todo.

$29 \int 8$ o do art. 37 da CF, atualmente em processo de regulamentação.

${ }^{30}$ Nesses casos, dada a relevância social e educacional desses programas, cuja execução era totalmente emperrada pela burocracia, adotou-se a figura do "repasse direto", uma sistemática que substituiu o convênio por um Termo de Adesão dos Municípios aos respectivos programas, eliminando a maioria das exigências burocráticas, o que permitiu as transferências regulares dos recursos federais respectivos para contas das prefeituras municipais e, no caso do Programa Dinheiro Direto na Escola, diretamente nas contas das associações de pais e mestres ou dos caixas escolares. A partir 
dessa nova sistemática, a alimentação escolar foi viabilizada, sem as constantes interrupções e ausências de antes, da mesma forma que o repasse dos recursos da manutenção escolar.

31 Contudo, diferentemente das áreas setoriais, os dirigentes municipais de administração ainda carecem de uma organização aglutinadora que facilite sua interface com as estruturas estaduais e federais. Apesar da sua importância, esses organismos não bastam para uma articulação mais efetiva. É preciso instituir mecanismos institucionalizados de coordenação da gestão pública que estruturem e integrem as principais funções administrativas nas três esferas de governo. É, particularmente, necessário conceber mecanismos que assegurem sinergia e integração aos processos de planejamento, implementação e avaliação das políticas públicas setoriais, em rede sistêmica, sem ferir a autonomia, a criatividade e a iniciativa de cada ente federado. A existência de instâncias institucionais de interlocução facilitaria a cooperação mútua e a superação de conflitos, o que sinaliza para a importância de organização de um conselho consultivo nacional, com participação de representantes do Consad, do Conseplan e dos dirigentes municipais de administração pública. O processo de descentralização administrativa no Brasil foi decisivo para a consolidação do regime democrático, reconquistado pela sociedade após os 20 anos de regime autoritário. Ele promoveu a cidadania, retirando o cidadão do ostracismo e da apatia que havia lhe sido imputado pela ditadura. Estimulou o compartilhamento de autoridade e de responsabilidade dos gestores públicos na implementação das políticas; envolveu a sociedade e pôs em xeque as instituições e institutos públicos arcaicos. Ao estabelecer novo pacto social e novo pacto federativo, a descentralização exigiu inovações na gestão pública, que nasceram das áreas setoriais e não mais do núcleo central administrativo do governo federal. As inovações empreendidas despertaram a atenção para a necessidade da revisão da estrutura sistêmica tradicional, com bases no Decreto-Lei no 200 , de 1967, o que resultou em uma separação estática entre as atividades administrativas auxiliares e as atividades finalísticas, uma separação estática entre governo e administração.

32 Friedrich Nietzche. Humano, demasiado Humano. São Paulo: Nova cultural, 1999, Obras Incompletas.

\section{Referências bibliográficas}

Brasil. Constituição Federal, Senado Federal, Edição atualizada de 1999.

Carvalho, Guido Ivan \& SAnTos, Lenir (2006): SUS Sistema Único de Saúde - Comentários

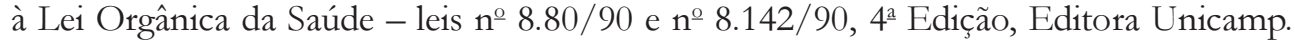
Christo Fernandes, C.; Graef, A.; Santos, L. A. (1994) Reforma do Estado e Administração Pública: Diagnóstico e Propostas para o Novo Governo. Brasília: mimeo. Christo Fernandes, C., Graef, A.; Santos, L. A. (1994) A questão do Regime Jurídico Único e suas implicações. Brasília: mimeo.

Fundação Centro de Formação do Servidor Público. No Presente com os Olhos no Futuro: uma Reforma Democrática. Brasília, 1988.

Graef, A. Mudança de Governo: Propostas para uma Reforma Administrativa Democrática. Brasília: Cadernos da ENAP, Vol 2 n. 4, 81-100

Milena, Antonio (2001): Gigantes do Bem, Revista Veja, Edição Especial de dezembro de 2001. 
Oliveira, Gustavo Justino e Mânica, Fernando Borges (2009). Parcerias na Saúde,

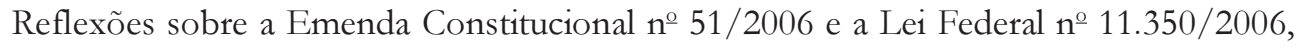
Editora Fórum.

Pessoa, Eneuton, Mattos, Fernando \& Britto, Marcelo. O emprego público não é excessivo no Brasil. Artigo publicado na edição de 18/01/2009 do jornal O Globo. Pires, Maria Coeli Simões \& Nogueira, Jean Alessandro Serra Cyrino (2009). O federalismo brasileiro e a lógica cooperativa-competitiva in Consórcios Públicos - Instrumento do Federalismo Cooperativo. Maria Coeli Simões Pires \& Maria Elisa Braz Barbosa (coordenadoras), Editora Fórum. 


\section{Resumo - Resumen - Abstract}

\section{Articulação Federativa na Prestação de Serviços Sociais no Brasil Aldino Graef}

O artigo analisa as mudanças na prestação de serviços públicos a partir da Constituição de 1988, quando um novo pacto federativo acompanhou a redemocratização política, resultando em ampla descentralização para estados e municípios, acompanhada de nova estrutura de repartição dos recursos tributários. Com esse objetivo, resgata-se o processo de formação de sistemas de prestação de serviços baseados na cooperação entre as três esferas de governo, focalizando as áreas de educação, saúde e assistência social. Discutem-se as inovações adotadas com a criação de formas organizacionais de negociação entre os entes federativos; a incorporação da participação social na formulação e controle das políticas públicas; a desburocratização dos fluxos de recursos financeiros e de informações; e a adoção de novos instrumentos jurídicos de descentralização de programas e ações. O texto aponta ainda os impactos dessa descentralização e das formas de articulação federativa, indicando a necessidade de novas reformas nos sistemas administrativos e na política de recursos humanos.

Palavras-chave: Descentralização, federalismo, serviços públicos, prestação de serviços.

\section{Articulación Federativa en la Prestación de Servicios Sociales en Brasil Aldino Graef}

El artículo analiza los cambios en la prestación de servicios públicos a partir de la Constitución de 1988, cuando un nuevo pacto federativo acompañó la redemocratización política, resultando en amplia descentralización para estados y municipios, en la que se ve una nueva estructura de reparto de los recursos tributarios. Con ese objetivo, se rescata el proceso de formación de sistemas de prestación de servicios basados en la cooperación entre las tres esferas de gobierno, focalizando las áreas de educación, salud y asistencia social. Se discuten las innovaciones adoptadas con la creación de formas organizacionales de negociación entre los entes federativos; la incorporación de la participación social en la formulación y control de las políticas públicas; la desburocratización de los flujos de recursos financieros y de informaciones; y la adopción de nuevos instrumentos jurídicos de descentralización de programas y acciones. El texto apunta también los impactos de esa descentralización y de las formas de articulación federativa, indicando la necesidad de nuevas reformas en los sistemas administrativos y en la política de recursos humanos.

Palabras Claves: Descentralización, federalismo, servicios públicos, prestación de servicios.

\section{Federative Articulation in the Provision of Social Services in Brazil Aldino Graef}

The article analyzes changes in the provision of public services, from the Constitution of 1988, when a new federative agreement followed the redemocratization policy, resulting in broad decentralization for states and counties, along with a new structure to share tax resources. With this objective, the text rescues the formation process of provision of services systems based on cooperation between the three spheres of government, focusing the areas of education, health and social welfare. The author discusses adopted innovations with the creation of organizational ways of negotiation between federative entities; the incorporation of the social involvement in the formulation and control of public policies; bureaucracy reduction of financial resources and information flows; and the adoption of new legal tools for program and action decentralization. The text also points out the impacts of that decentralization and of the federative ways of articulation, indicating the need for new reforms in the administrative systems and in human resources policy.

Keywords: Decentralization, federalism, public services, provision of services. 


\section{Aldino Graef}

Graduado em História e especialista em Políticas Públicas e Gestão Governamental (ENAP). Possui mestrado incompleto em economia (Universidade de Estocolmo). Atualmente, exerce a função de Diretor do Departamento de Articulação Institucional da Secretaria de Gestão do Ministério do Planejamento, Orçamento e Gestão. Contato: aldino.graef@planejamento.gov.br 